\title{
Tensions Experienced by Rural Teachers in Adopting Tablet Teaching in Taiwan
}

\author{
Lih-Juan Chan-Lin \\ Department of Library and Information Science, Fu Jen Catholic University, Taiwan \\ Email: lins1005@mail.fju.edu.tw
}

Received 15 May 2016; accepted 24 July 2016; published 27 July 2016

Copyright (C) 2016 by author and Scientific Research Publishing Inc.

This work is licensed under the Creative Commons Attribution International License (CC BY). http://creativecommons.org/licenses/by/4.0/

(c) (i) Open Access

\begin{abstract}
This study explored teachers' tension to the integration of tablet teaching in rural schools in Taiwan. Rural teachers adopting mobile teaching were invited to respond to survey questionnaire items designed for the study. Teachers' technology knowledge (TK) and their tensions to integrating mobile teaching were assessed. Factor analyses were employed to elicit five constructs from the tension factors. Among these constructs, the teachers were most concerned about "policy and support". In a comparison of teachers' adoption of different tools (tablets vs. portable computers), teachers adopting tablets for mobile teaching had a higher level of technology knowledge (TK) than those using portable computers $(p<0.01)$, and a higher tension level for "policy and support" $(p<0.01)$ and "pedagogy concerns" $(p<0.05)$.
\end{abstract}

\section{Keywords}

Technology Integration, Mobile Learning, Tablet Learning, Rural Teaching, Teacher Tensions

\section{Introduction}

The rapid proliferation of tablet devices has made Internet access and ubiquitous learning important educational trends, both now and presumably in the future. The development of device-specific resources that optimize the mobility of learning is also accelerating the popularity and personalization of mobile learning (Nedungadi \& Raman, 2012). Teachers are encouraged to adopt various innovative approaches for engaging students in activities with different tablet devices for accessing and exploring diverse learning resources (Riley, 2013; Scott, 2014). However, children in rural areas and from low socio-economic families might not be able to afford these devices to fulfill the needed experience with mobile technology. Many children perform comparably on achievement tests without the advantage of a broad curriculum or access to a wide variety of opportunities (Fowler, 2012). Rural teachers have to deal with the problems due to limit financial resources and funding. To 
equip these children with the literacy required in the digital age, teachers also experience tensions and challenges with integration of mobile technology into their classrooms. Establishing foundations for connecting knowledge and resources and providing sustainable implementation are concerned by most rural teachers (Chanlin, Lin, \& Lu, 2015; Schlicht, 2013). In this study, tensions to adapting different tools for mobile teaching among rural teachers are studied. Issues related to these factors are discussed.

\subsection{Theoretical Foundation}

Teachers engaging in the integration of technologies hope that it will transfer the learners' experiences in a positive way, increase students' achievement, and help them achieve the learning goals (Laferrière, Hamel, \& Searsont, 2013). Although the integration of mobile technology into the classroom has the potential to improve teaching and learning, teachers at rural schools often experience with tensions and lack the support required to fulfill their teaching needs (Phiri, Foko, \& Mahwai, 2014). Laferrière et al. (2013) use Activity Theory (Engeström, 1987) to explain the dynamics of technology barriers and essential conditions experienced by individuals to adopt new tools for mediating interaction in a given community. Personal adoption of technology can be interpreted by Activity Theory as an approach for different forms of human praxis interlinked within personal and environmental factors throughout the developmental process (Liaw \& Huang, 2014). The theoretical framework underpinning teachers' activity in the integration of technology is structured by: activity motive, actions toward goals and operations influenced by conditions (Laferrière et al., 2013; Leont'ev, 1978). Based on this interpretation, factors for adoption should be analyzed within a dynamic system, not as separate entities. Operation conditions within the school and the surrounding community might influence teaching practice of technology integration. Borrowed from Activity Theory, when new technology (e.g., tablet computers) is introduced for reaching new goals, teachers are often challenged by their knowledge about adopting the technology (the tool), the policies of the authority (the rule), support from their school and society (community), and time allocation for planning courses/pedagogy (division of labor) (Figure 1).

In the transition from portable computers (the traditional tool for mobile learning) to tablet computers (a new tool for mobile learning), teachers might need to deal with problems of exploring, planning pedagogy change, searching for a platform for classroom implementation, and facilitating children's access to the tools for new learning. Jaradat, Qablan and Barham (2011) recognized relevant internal and external factors within and across communities, ranging from curriculum implementation, management of class, and engaging students in higher order thinking.

Teachers play a very important role in providing children with a technology-supported learning environment. When rural teachers introduce new technology for reaching new education goals, they often challenged by the existing tension in the use of tools, the role they play, and policies for the support of teaching and learning. Potential barriers exist for teachers in technology implementation (Hew \& Brush, 2007; Laferrière et al., 2013).

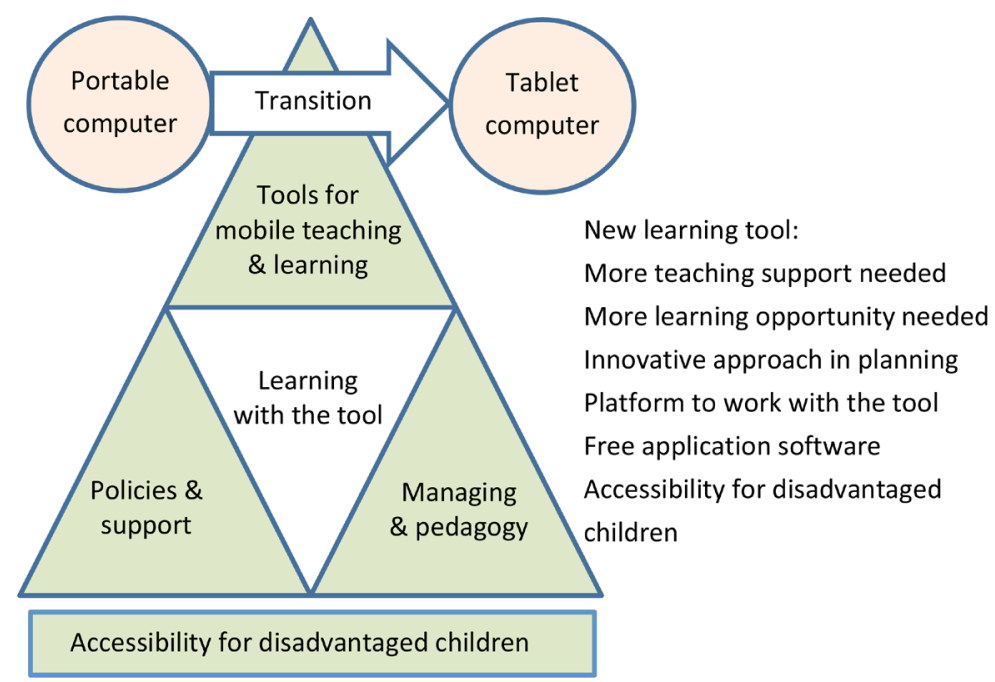

Figure 1. Theoretical foundation for tablet teaching borrowed from activity theory. 
Most rural teachers might experience insufficient support to explore the use of new mobile technology, or fail to leverage the potential of technology for a unique purpose due to uncertainty about the unique use of mobile tools to support student-centered practices, and instead, try to fit it into their already set curricula. Appropriate knowledge of integration, technology beliefs, traditional practices, and value to learning are indicators of implementation decisions by teachers (Blackwell, 2013; Peterson, 2011). Teaching in remote schools, teachers have to deal with more complex issues because of the low socio-economic status and diverse classroom structure existing among these disadvantaged groups (Chan Lin, Lin, \& Lu, 2015).

Facing tremendous challenges in terms of academic achievement (Celano \& Neuman, 2010), children in rural areas require special attention in various domains to support their learning, including learning resources, facilities and human resources (Banister \& Reinhart, 2011). Pedagogical issues for effective interaction, administrative support, free wireless access, and collaboration among school teachers are also important factors for successful implementation (Binsaleh \& Binsaleh, 2013).

\subsection{Pedagogical Concerns for Rural Communities}

The problems to access to information and technology among underserved communities have been addressed by Kumbargoudar (2013), including illiteracy, poverty, lack of computer literacy, lack of widespread communication facilities and limited power supply. Challenges were experienced in facilitating children's connectivity to the knowledge world through the use of technology, especially with limited digital access to available information and learning resources (Celano \& Neuman, 2010; Chanlin et al., 2015). A great majority of children in rural areas are also from low-socioeconomic-status families, and face significant barriers that typically persist through their school years (Oyserman, 2012). Khan, Hasan and Clement (2012) identified factors necessary for bridging the digital gap among diverse populations. These factors include infrastructure, funding for resources, and policy supports. Facilitation with innovative teaching approaches entails more support of affordable pathways for both teachers and children (Jill \& Penny, 2010; Kumbargoudar, 2013; Schlicht, 2013). From the concept of Activity Theory, the interactions of human actions and consciousness within its relevant environmental contexts are essential for studying human behaviors (Kuutti, 1995). Issues related to providing scaffolding for instructional, social, technical, and managerial approaches are essential considerations for encouraging a connective mobile teaching and learning environment (Ozan, 2013).

Looking at the interactions among the tool, rules, community, and division of labor as addressed in Activity Theory, the important attribute of a mobile device for achieving the intended objectives should be considered in the planning and in managing the pedagogy for the use of the tools. Sharples et al. (2005) distinguish mobile learning from other types of learning activities, as it involves learners learning across space, and taking ideas and learning resources gained in one location and applying them in another. To achieve the intended goals, individuals should be consciously involved in tasks, such as focusing attention on and accessing cognitive resources to perform an action (Martinez, 2010; Kuutti, 1995). Park (2011) emphasized "portability" as one of the important technological attributes and pedagogical affordances of mobile learning. Teachers designing classroom activities should carefully consider the personalized, learner centered, situated, and ubiquitous features of mobile learning (Park, 2011; Sharples et al., 2005). Planning appropriate device-dependent learning content, contextaware ubiquitous learning, and pedagogical strategies in mobile learning activities (for action in complex and social situations) are demanding tasks for teachers (Jeng et al., 2010).

Factors influencing teachers' integration of mobile technology into classrooms are interconnected with the mobility orientation of devices and management in remote schools' learning settings. Blackwell (2013) notes technological difficulties and misuse among children in their adoption of technology. Teachers play an important role in the control and management of activities for guiding children in the appropriate use of technology to achieve their intended objectives (Liaw \& Huang, 2014). As suggested, successful technology integration is determined by many interrelated factors of the tool, context, management, and community. These factors include the cost of the infrastructure, technical services, usability-system design, necessary roles for initiating and supporting mobile learning, enabling new instructional activities, and administrative tasks for the use of mobile technology (Binsaleh \& Binsaleh, 2013; DiVall \& Zgarrick, 2014). Diaz, Moro \& Carrión (2015) and Kearney et al. (2012) emphasized the importance of the pedagogical aspects of planning for students' mobile learning, revealing that more time and effort have to be spent employing pedagogical approaches, especially for planning space and time for learning activities (Kearney et al., 2012). The innovative use of technology requires the sharing of needed resources and various use patterns among teachers (DiVall \& Zgarrick, 2014). 


\subsection{Concerns Regarding the Use of Tools}

The affordances of and factors in technology integration are further highlighted in educating children in rural schools, where many children have limited access to technology. In the past, factors for adopting new technology in learning and teaching have been addressed. These factors include: proficiency with and knowledge of technology, institutional support, pedagogical integration, the reliability of the technology, and technical support for the technology (Butter \& Sellbom, 2002; Hew \& Brush, 2007; Khan et al., 2012; Laferrière et al., 2013). When addressing factors for adopting technology in teaching, the TPACK model has been used in many studies to focus on teachers' subject domain (content) knowledge and their knowledge of teaching with technology in specific domains (pedagogical) (Shulman, 1986; Schmidt et al., 2009; Mishra \& Koehler, 2006). These studies propose teachers' perspectives on using ICT in teaching from a knowledge-based research framework, emphasizing different domains of concern in the use of technology in teaching, including technological, pedagogical, and content knowledge. Al-Senaidi, Lin and Poirot (2009) identified both internal and external factors of adapting ICT (information communication technology) among teachers, including: tools, support, beliefs, confidence, and time. Hew and Brush (2007) also summarized various aspects of factors for integrating technology into curricula, including: resources, subject culture, attitudes and beliefs, knowledge and skills, and assessment. Integrating or infusing a new technology into teaching involves internal psychological factors and beliefs perceived by teachers, and processes of familiarization, utilization, integration, re-orientation, and evolution (Al-Senaidi et al, 2009; Ducate \& Lomicka, 2013). When considering building children's technology experiences and knowledge skills, working with diversity and helping children develop technology literacy for present and future learning should also be considered (Henderson, 2011).

In contrast with a traditional classroom setting, re-conceptualizing learning for the mobile age is essential for the design of student-centered learning environments (Sharples, Taylor, \& Vavoula, 2005). Since teaching with mobile devices entails effort in planning classroom activities, administrative support to identify resources and strategies is needed to enhance teaching practices (DiVall \& Zgarrick, 2014). Fabian \& Maclean (2014) identified potential pitfalls in the use of mobile devices in teaching and learning activities. Problems related to unfamiliarity and administrative setups (charging the devices, app updates, and management of personal data) have been found.

In this study, influencing factors for adapting mobile technology in teaching and learning in rural schools are explored. Teachers' experience of the use of different tools (portable computer vs. tablet) might have different influences on these factors. Specifically, the following questions were explored:

1) What are the tensions experienced by teachers in the integration of mobile learning for teachers in rural schools? 2) How can these tensions be categorized into particular constructs? 3) Do teachers adopting different tools (portable computer vs. tablet) exhibit differences in their perceived technology knowledge (TK)? 4) Do teachers adopting different tools (portable computer vs. tablet) react differently to these tension factors?

\section{Method}

\subsection{Setting in Rural Schools}

In Taiwan, many children in rural communities have been viewed as unmotivated due to low learning achievement as they progress through school. Because of their disadvantaged family socioeconomic status, inadequate education resources are experienced in the rural schools. Economic necessity has driven change in the pattern of life of many rural families. Many teachers have to deal with underachieving problems and related issues due to the diverse socio-economic status of these children. However, teachers strive to integrate innovative teaching strategies and to help children learn from their own culture and life (Middleton, Dupuis, \& Tang, 2013).

To promote a ubiquitous learning environment in schools, the Ministry of Education has initiated the project "Mobile Learning Project for Elementary and Secondary Schools" (Ministry of Education in Taiwan, 2014). In this project, leadership is provided to guide mobile teaching and learning practice. Executive communities among school teachers are organized to share experiences of innovative approaches from different learning sites. Although some rural schools have participated in their project, they might need to deal with complex issues existing in the rural communities.

Compared with portable computers commonly adopted by most rural schools, the use of tablets for mobile teaching is relatively new. To explore with tablets in teaching, some schools obtain the devices from grant pro- 
posals applied with different organizations, institutes, and charity foundations. It is speculated that teachers with different tools used for mobile teaching might react differently, including: their knowledge level in the use of mobile technology and experienced tensions to the integration of mobile teaching. In this study, teachers with experience in mobile teaching implementation were invited to respond to the issues addressed in a set of pre-determined questions.

\subsection{Tools for Assessment}

A set of questionnaire items was developed to assess the tension factors in integrating mobile teaching among rural teachers. Teachers from rural schools with experience in mobile learning were invited (through email invitations, meetings, and conferences) to fill out the online questionnaire. The first part of the questionnaire assessed the teachers' demographic information, and personal attributes, including school, years of teaching, subject areas of teaching, personal use of tablet and current use of tablet for mobile teaching. The second part of the questionnaire items used 1 - 5 points to assess the teachers' capability level, and their tensions to the integration of mobile teaching.

Ten questionnaire items used to assess the teachers' technology knowledge (TK) of mobile teaching were adapted partially from previous research (Shulman, 1986; Schmidt et al., 2009; Mishra \& Koehler, 2006) (Table 1) and were revised to reflect the teachers' technology knowledge relevant to mobile teaching practice in rural schools in Taiwan. These items aimed to assess the teachers' capability and actions for enabling children's essential learning skills supported by mobile technology.

Another 27items which aimed to explore tension factors influencing teachers in terms of their mobile teaching were identified. These factors were derived from the supportive conditions addressed in Activity Theory (Laferrière et al., 2013) and related literature from various areas, including: information gaps and learning in rural communities (ChanLin et al., 2015), pedagogical concerns (Park, 2011; Sharples et al., 2005), personal factors (Al-Senaidi et al., 2009), technology and social issues (Ozan, 2013), policy issues (Blackwell, 2013; Schlicht, 2013), institutional support (Butler \& Sellbom, 2002; Khan, et al., 2012), and equality of digital access for disadvantaged communities (Kumbargoudar, 2013) (Table 2). These items were also referenced from policies and social issues of concern to school teachers in the rural areas of Taiwan, and were tentatively categorized into various facets: personal factors, support and resources, pedagogical concerns, policy, and special care for underachieving children and children from low-income families.

In the questionnaire, a 1 to 5 point Likert scale was used to elicit teachers' responses to each factor item for assessing teachers' technology knowledge and their tensions in mobile teaching. Prior to the survey investigation, the questionnaire items were evaluated for the construct indicators by two experts in the domain of technology integration in rural schools. Revisions were made according to the suggestions provided by the reviewers. In addition, a pretest among 5 teachers was also conducted to guarantee the clarity of the instrument.

\section{Table 1. Teachers' technology knowledge level for the integration of mobile learning.}

\section{Item}

1. I enjoy using various innovative technologies.

2. I keep up with new mobile technologies relevant to learning and teaching.

3. I actively search for application software for specific knowledge content of my interest.

4. I am able to solve technological problems on my own.

5. I often share with friends what I have learned with mobile teaching applications.

6. In exploring mobile learning, I know the importance of building existing knowledge to develop new understanding among children.

7. I often attend mobile teaching training to learn innovative adaptation.

8. I frequently update my knowledge of various mobile applications relevant to pedagogy and knowledge content.

9. In my teaching, various mobile exploration opportunities for knowledge among children are encouraged.

10. I feel capable of guiding students to experience learning of knowledge through mobile learning opportunities. 
Table 2. Adoption factors from Activity Theory.

\begin{tabular}{|c|c|c|}
\hline Activity Theory & Derived factors & Items for eliciting tension responses \\
\hline Tool & $\begin{array}{l}\text { Use of the tools } \\
\text { Available application and platform }\end{array}$ & $\begin{array}{l}\text { Access to mobile learning opportunities } \\
\text { among disadvantaged children. } \\
\text { Experience of using mobile devices among children }\end{array}$ \\
\hline Rules & $\begin{array}{l}\text { Government policy } \\
\text { Support policy for mobile teaching }\end{array}$ & $\begin{array}{c}\text { Supportive policy for mobile teaching } \\
\text { Shareable resources provided by the authority } \\
\text { Grants provided by the authority } \\
\text { Support of manpower for children with special learning needs }\end{array}$ \\
\hline Division for labor & $\begin{array}{l}\text { Management of time and effort } \\
\text { Planning effort needed for the activity } \\
\text { Pedagogy concerns }\end{array}$ & $\begin{array}{l}\text { Time and effort for planning mobile teaching. } \\
\text { Difficulty in planning interactions for mobile teaching } \\
\text { Teaching of specific subject areas }\end{array}$ \\
\hline Community & $\begin{array}{l}\text { Teaching and learning community } \\
\text { Children in remote schools } \\
\text { Underachieving children } \\
\text { Children from low-income families }\end{array}$ & $\begin{array}{l}\text { Mobile teaching community } \\
\text { Interaction within the community } \\
\text { Underachieving children with special needs in learning } \\
\text { Accessibility among disadvantaged (low-income) children }\end{array}$ \\
\hline
\end{tabular}

\subsection{Analysis of Data}

Questionnaires were gathered for statistical analyses. Factor analysis was used to determine the tension constructs of integrating mobile technology into the classroom. The factor analysis process involved the following steps: selecting the variables to be analyzed, computing the correlation matrix and determining whether or not to proceed with factor analysis, estimating communalities, rotating the factor axes, and explaining the factors.

\section{Results}

\subsection{Teachers' Use of Tablets and Knowledge of Technology}

The study subjects were teachers who integrated mobile teaching in remote schools. A total of 101 teachers (from 7 remote areas) in Taiwan responded to the questionnaires. Among them, 93 were 1st-6th grade teachers, and 8 were 7 th -9 th grade teachers. Only $26(25.7 \%)$ were teachers of information technology, while 75 (74.3\%) taught other courses (including: language $22.7 \%$, math $12.9 \%$, social science $10.3 \%$, health and physical education $9.3 \%$, nature and life science $17.5 \%$, art and literature $17.5 \%$, and environmental education 5.7\%). Their experience of teaching varied as follows: $16.8 \%$ had " 0 - 5 years", $15.8 \%$ had "5 - 10 years", $26.7 \%$ had "10 - 15 years", and $41 \%$ had "more than 15 years" of teaching experience. Demographic data for device use (current use for mobile teaching) show that $48 \%$ of the teachers used portable computers, and $52 \%$ used tablets (all Android devices). In response to the budget for tablets: 13 teachers (24\%) funded their tablets from personal submission of grant proposals (with different organizations); 21 (39\%) from collaborative grants obtained by their schools; 12 (22\%) from their school budget; 13 (24\%) from their personal budget; 13 (24\%) from donations; and 12 (22\%) from others (Table 3).

The teachers' knowledge of technology integration for mobile learning was assessed. Reliability analysis using Cronbach's Alpha was 0.911 for the 10 questionnaire items. Teachers' technology knowledge (TK) of the integration of mobile learning ranged from 1.8 to 5.0, with a mean of $4.09( \pm 0.593)$, indicating variation in their capability to use technology in teaching. Various learning platforms and software were used by the teachers, including Eucoco, Junyi Academy, ITS5, IRS, Monkey, Moodle, and Hi-Tech Interactive.

\subsection{Factors for Integration of Mobile Technology in Teaching}

Factor analysis was used to identify tension factors for integrating mobile technology into teaching. The Barlett Sphericity test was performed to determine the aptitude of the data. The KMO value was found to be $0.808\left(\mathrm{X}^{2}\right.$ $=1863.057, p=0.000$ ) (labelled as "middling"), which is appropriate for factor analysis as suggested by Kaiser (1974). Principal Component Analysis was used to extract the factors, and then rotated by a Promax with Kaiser Normalization. Factor structures were evaluated according to the following criteria: a) eigenvalues were greater than or equal to $1 ; b$ ) each factor accounted for greater than $5 \%$ of the total variance; c) each factor demonstrated adequate internal consistency, with alpha coefficients greater than or equal to 0.70 . 
Table 3. Current use of tool for mobile teaching and budget for tablets.

\begin{tabular}{cc}
\hline Current tool & Reponses \\
\hline Portable computer & $48(48 \%)$ \\
Tablet & $53(52 \%)$ \\
& Personal submission of grant proposal: $13(24 \%)$ \\
$\begin{array}{c}\text { Budget for } \\
\text { obtaining tablets } \\
\text { (from 53 respondents) }\end{array}$ & Collaborative grant obtained by the school: $20(38 \%)$ \\
& School budget: $12(22 \%)$ \\
\hline
\end{tabular}

From the analyses, five major factors were elicited among the 27 items: 1) Policy and support, 2) Effort for engaging children, 3) Pedagogy concerns, 4) Management, and 5) Accessibility for disadvantaged children. The factors and item loadings for each category are listed in Tables 3-7. The accumulated variance reached $65.718 \%$. The homogeneity of each factor analyzed using Cronbach's Alpha revealed satisfactory results in the reliability analyses in alpha value: $0.922,0.844,0.760,0.800$, and 0.752 for each category (Tables 4-8). The Cronbach's Alpha for all items was 0.840 .

Factor I is named "Policy and support," and refers to the need for incentives provided by the education authority and policies to support teaching with mobile technology in the classroom, including teaching societies and platforms to share experiences of teaching, as well as needed grants and resources for innovative mobile teaching. Factor I covers 7 items. The means for each item in "Policy and support" are summarized in Table 4.

Factor II is named "Effort for engaging children" which refers to the effort teachers must make to engage in mobile learning among children with special needs. Many children from rural families are characterized as having a low socioeconomic status (SES). They require additional technology experience and opportunities for learning with technology. Nurturing these children with special needs entails special attention. Factor II in this category covers 7 items to reflect teachers' concern with special needs among children. The means for each item in "Effort for engaging children" are summarized in Table 5.

Factor III is named "Pedagogy concern", and refers to the factors for planning class activities in teaching specific subject areas with mobile devices. Pedagogical issues related to the implementation of mobile teaching cover the application software, resources, and interactive platforms for teaching and learning interactions. Much effort for planning is required. Factor III covers 5 items. The means for each item in "Pedagogy concerns" are summarized in Table 6.

Factor IV is named "Management," and refers to the tensions to teachers' engagement in offering mobile exploration opportunities to children, including the arrangement of children's involvement, insufficient capability for integration, children's learning obstacles, difficulties in planning, and coping with problems. Factor IV covers 6 items. The means for each item in "Management" are summarized in Table 7.

Factor V is named "Accessibility for disadvantaged children" and refers to the tensions to accessibility to technology for disadvantaged children. Factor V covers 2 items. The means for each item in "Accessibility" are summarized in Table 8.

Among various factor constructs, the teachers were most concerned about "Policy and support" $($ Mean $=4.26$, $\mathrm{SD}=0.566$ ). "Accessibility for disadvantaged children", was rated as the second (Mean = 3.67, $\mathrm{SD}=0.907$ ), and "Pedagogy concern" as the third (Mean $=3.52, \mathrm{SD}=0.694)$. Less tensions were found in "Management" $($ Mean $=2.89, \mathrm{SD}=0.727)$ and "Effort for engaging children" $($ Mean $=2.94, \mathrm{SD}=0.714)$.

\subsection{Comparison in Use of Tools for Mobile Teaching}

Teachers adopting different tools (tablets vs. portable computers) for mobile teaching were compared in their technology knowledge (TK). Statistical analysis using a t-test indicated a significant difference between the two groups. Teachers who used tablets in their teaching perceived a higher level of technology knowledge (TK) than those using portable computers for mobile teaching $(\mathrm{t}=2.712, p=0.008)$ (Table 9). 
Table 4. Factors for "Policy and support".

\begin{tabular}{|c|c|c|c|}
\hline Item for Factor I: Policy and Support & Loading & Mean & SD \\
\hline $\begin{array}{l}\text { 1. A teacher community supervised by the authority should have } \\
\text { provided more leadership in mobile teaching. }\end{array}$ & 0.898 & 4.31 & 0.703 \\
\hline 2. I have difficulty accessing shareable resources to support innovative mobile teaching. & 0.897 & 4.25 & 0.623 \\
\hline $\begin{array}{l}\text { 3. The government should provide platforms for distributing } \\
\text { quality teaching resources for mobile teaching. }\end{array}$ & 0.854 & 4.34 & 0.652 \\
\hline 4. Insufficient project grants are provided for supporting high quality mobile teaching models. & 0.817 & 4.32 & 0.734 \\
\hline $\begin{array}{l}\text { 5. I have difficulty planning appropriate mobile learning } \\
\text { content for disadvantage children who need special attention. }\end{array}$ & 0.806 & 4.19 & 0.731 \\
\hline 6. Sufficient mobile devices should be provided by the government for supporting mobile learning. & 0.793 & 4.20 & 0.648 \\
\hline 7. Sufficient mobile devices should be provided by the government for supporting mobile learning. & 0.788 & 4.16 & 0.758 \\
\hline Sub mean & & 4.26 & 0.566 \\
\hline
\end{tabular}

Factor I (Variance: $26.252 \%$; Alpha value: 0.922 )

\section{Table 5. Factors for "Effort for engaging children".}

\begin{tabular}{|c|c|c|c|}
\hline Item for Factor II: Effort for engaging children & Loading & Mean & $\mathrm{SD}$ \\
\hline $\begin{array}{l}\text { 1. I feel there is a lack of manpower for involving underachieving } \\
\text { children in independent mobile learning activities. }\end{array}$ & 0.728 & 3.28 & 1.055 \\
\hline 2. Monitoring and providing timely guidance for underachieving children is difficult. & 0.720 & 3.47 & 0.989 \\
\hline $\begin{array}{l}\text { 3. Extra effort is needed to support mobile learning experience } \\
\text { among underachieving children. }\end{array}$ & 0.719 & 2.63 & 0.956 \\
\hline $\begin{array}{l}\text { 4. Underachieving children are less experienced with mobile learning } \\
\text { and are frustrated with mobile technology. }\end{array}$ & 0.714 & 2.60 & 0.991 \\
\hline $\begin{array}{l}\text { 5. Underachieving children are reluctant to explore new knowledge } \\
\text { with mobile technology. }\end{array}$ & 0.694 & 2.58 & 1.022 \\
\hline $\begin{array}{l}\text { 6. I have difficulty adapting teaching models from other teachers for } \\
\text { engaging children's learning. }\end{array}$ & 0.676 & 3.00 & 0.872 \\
\hline 7. I have difficulty helping children attend to relevant learning with mobile devices. & 0.648 & 3.03 & 1.109 \\
\hline Sub mean & & 2.94 & 0.714 \\
\hline Factor II (variance: $19.36 \%$; Alpha value: 0.844 ) & & & \\
\hline
\end{tabular}

\section{Table 6. Factors for "Pedagogy concern".}

\begin{tabular}{|c|c|c|c|}
\hline Item for Factor I:Pedagogy concern & Loading & Mean & SD \\
\hline 1. I feel there is limited free application software available for mobile teaching. & 0.866 & 3.48 & 0.923 \\
\hline 2. I feel there are limited free learning resources available for mobile teaching. & 0.797 & 3.46 & 0.944 \\
\hline 3. The software available for mobile teaching is quickly outdated. & 0.763 & 3.34 & 0.924 \\
\hline $\begin{array}{l}\text { 4. It is time-consuming for me to select and organize appropriate } \\
\text { mobile learning content for children. }\end{array}$ & 0.732 & 3.92 & 0.770 \\
\hline 5. Limited applications are available in my teaching domains. & 0.605 & 3.40 & 0.939 \\
\hline Sub mean & & 3.52 & 0.694 \\
\hline Factor III (variance: 9.21\%; Alpha value: 0.760 ) & & & \\
\hline
\end{tabular}


Table7. Factors for "Management".

\begin{tabular}{lccc}
\hline \multicolumn{1}{c}{ Item for Factor VI: Management } & Loading & Mean & SD \\
\hline 1. I feel that children are not interested in the designed mobile learning activities. & 0.822 & 2.44 & 0.963 \\
2. I have insufficient skills with information technology. & 0.764 & 2.80 & 1.114 \\
3. Children often experience technology barriers in their use of mobile applications. & 0.748 & 2.96 & 0.953 \\
4. It is difficult to plan frequent interactions with mobile teaching. & 0.716 & 3.12 & 1.003 \\
5. I feel helpless when encountering problems in mobile teaching. & 0.658 & 2.74 & 0.868 \\
6. It is time-consuming to plan mobile learning activities. & 0.625 & 3.29 & 0.920 \\
Sub mean & & 2.89 & 0.727 \\
\hline
\end{tabular}

\begin{tabular}{|c|c|c|c|}
\hline Item for Factor VI: Accessibility for disadvantaged children & Loading & Mean & SD \\
\hline $\begin{array}{l}\text { 1. It is difficult to provide adequate access to mobile learning } \\
\text { at my school to support disadvantaged children. }\end{array}$ & 0.883 & 3.68 & 1.039 \\
\hline 2. Disadvantaged children have insufficient experience in the use of mobile devices. & 0.820 & 3.66 & 0.993 \\
\hline Sub mean & & 3.67 & 0.907 \\
\hline Factor V(variance: $5.75 \%$; Alpha value: 0.752 ) & & & \\
\hline
\end{tabular}

Table 9. Comparison of technology knowledge level in mobile teaching.

\begin{tabular}{ccc}
\hline Tool for mobile teaching & Technology knowledge Mean (SD) & Comparison \\
\hline Tablet $(\mathrm{N}=48)$ & $4.22 \pm 0.51$ & $\mathrm{t}=2.712, p=0.008^{* *}$ \\
Portable computer $(\mathrm{N}=53)$ & $3.94 \pm 0.65$ &
\end{tabular}

$$
{ }^{* *} p<0.01
$$

Teachers adopting different devices for mobile teaching were also compared regarding their perceived tensions to integration using at-test. Significant differences were found whereby teachers using tablet computers perceived a higher level of tension for Factor I and Factor III $(p<0.05)$. Teachers teaching with tablets perceived a higher level of tension in "Policy and support" $(\mathrm{t}=2.663, p=0.009)$ and "Pedagogy concerns" $(\mathrm{t}=$ $2.051, p=0.043)$. However, no significant differences were found in Factor II, Factor IV, or Factor V $(p>0.05)$ (Table 10).

\section{Discussion}

With a touch screen and intuitive operation features in mobile learning, tablets are appealing to many children, and are considered to have the potential to enhance their emergent literacy skills (Neumann \& Neumann, 2014; Phiri et al., 2014). In order to provide children with the innovative learning experiences, many rural teachers have adopted tablets into their teaching. In this study, it is observed that $52 \%$ of rural teachers have integrated tablets for mobile teaching. These teachers searched for various outsourced support to meet their needs. The results of the study also indicate that teachers who adopted tablet teaching perceived a higher level of technology knowledge in mobile teaching $(p<0.01)$. More exposure to the use of tablets in teaching allows teachers to gain more experience of exploring applications for promoting peer or teacher-children interactions in the classroom (Geist, 2014; Karlsudd, 2014). However, from their experience of integration, teachers might encounter tensions to implementation.

An examination of teachers' tensions to integrating mobile teaching from Activity Theory is important for identifying obstacles to the implementation of mobile learning in rural schools. From the factor analysis, five 
Table10. Comparison of perceived tension level of teachers for using different devices.

\begin{tabular}{lcccc}
\hline \multicolumn{1}{c}{ Tension construct } & $\begin{array}{c}\text { Tablet } \\
(\mathrm{N}=48)\end{array}$ & $\begin{array}{c}\text { Portable computer } \\
(\mathrm{N}=53)\end{array}$ & $\mathrm{t}$ & $\mathrm{p}$ \\
\hline Factor I: Policy and support & $4.39 \pm 0.51$ & $4.11 \pm 0.59$ & 2.663 & $0.009^{* *}$ \\
Factor II: Effort for engaging children & $2.82 \pm 0.75$ & $3.08 \pm 0.65$ & -1.823 & 0.071 \\
Factor III: Pedagogy concern & $3.65 \pm 0.78$ & $3.37 \pm 0.55$ & 2.051 & $0.043^{*}$ \\
Factor IV: Management & $2.94 \pm 0.65$ & $2.85 \pm 0.80$ & -0.669 & 0.505 \\
Factor V: Accessibility for disadvantaged children & $3.75 \pm 0.97$ & $3.59 \pm 0.81$ & -0.835 & 0.406 \\
${ }^{*} p<0.05 ;{ }^{* *} p<0.01$. & & & &
\end{tabular}

tension factors were elicited and named: "Policy and support", "Effort for engaging children", "Pedagogy concerns", "Management", and "Accessibility for disadvantaged children". Among the various tension factors, the teachers were most concerned about the tensions of "Policy and support" (Mean $=4.26, \mathrm{SD}=0.566)$. Similar concern has been addressed in the literature in the analysis of teachers' tension factors when integrating technology in the digital age (Afshari et al., 2009; Collier, Burkholder, \& Branum, 2013; Khan et al., 2012; Schlicht, 2013; Tondeur et al., 2008). The related literature highlights the importance of policy and support in teaching resources and training opportunities for fostering teachers' involvement in mobile learning (Blackwell, 2013; Khan et al., 2012; Tondeur et al., 2008).

Being isolated from space and distance, teachers in remote schools also experience hindrances in the shortage of manpower, and a great majority of underachieving and disadvantaged children with special needs. Equity use of technology among disadvantage communities entails more policy support for teachers' implementation of mobile teaching (Khan et al., 2012; Laferrière et al., 2013). To cope with the tensions in integration, various approaches are suggested by Blackwell (2013) and Schlicht (2013), including: support and leadership from the authority, funding support, guidance regarding the use of resources and freeware, and policies for children with special needs. Pedagogy concern regarding free and sharable resources, development of sharable knowledge among teachers, and skills in coaching children is also emphasized (Figure 2).

Compared with traditional mobile learning using portable computers, a higher level of tension from "Pedagogy concern" was also found among teachers using tablets for mobile teaching $(p<0.01)$. It is speculated that these teachers' concerns might be derived from the problems they encountered in experimenting with the new teaching device. Al-Senaidi et al. (2009) point out the tension of time and effort for exploring with the new approach of tablet learning when preparing content for lessons. It is also suggested that support for training and an appropriate platform used for technology integration in schools is needed (Khan et al., 2012). Local software companies should be encouraged to work with teachers to develop suitable platforms that are affordable and convenient to use, and encourage interaction of knowledge through tablet teaching and learning activities

In our study, a higher level of tension for "Pedagogy concerns" $(p<0.05)$ perceived by teachers using tablets reveals the need for sufficient opportunities to foster the development of teaching strategies and problem-solving capability in the adoption and planning of mobile learning activities in the classroom. As addressed by previous literature (Gerard, Knott, \& Lederman, 2012; Khan et al., 2012; Watson \& Watson, 2011), technology integration in the classroom is also a learning process for the teachers. Components of interactive teaching processes, such as giving immediate feedback, diagnosing specific children's problems, and offering effective remediation are essential capabilities which need to be developed along with the process of adoption. This might explain why teachers with tablet teaching perceived a higher level of technology knowledge in their mobile teaching ( $p$ $<0.01)$.

Effective implementation of tablet teaching requires commitment from the authority, school administrators, teachers, students and all the stakeholders within the community. Being aware of the importance of children's learning in the technological generation among the community, the educational authority should strive to overcome the barriers which prevent technology integration, so that children can benefit from it (Khan et al., 2012). Mobile teaching and learning in the classroom requires policy support for reorganizing and restructuring technology integration from authority leadership. Sufficient funding, training opportunities, professional development, and time for planning among teachers are also critical for effective integration. Equity of access to resources among children with special needs should also be emphasized. 


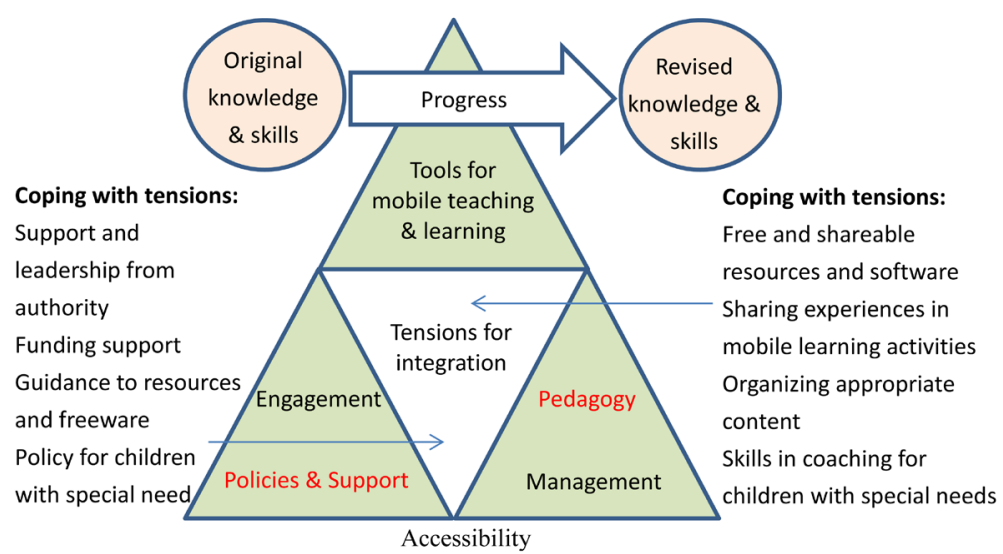

Figure 2. Coping with tensions to the integration of tablet teaching.

\section{Conclusion}

In this study, rural teachers' tensions to the adoption of mobile teaching were explored. Various factors were identified. Rural teachers face challenging issues when working with diversity and helping children develop technology literacy. Children's learning opportunities might be limited if sufficient exposure to technology is not provided by their schooling. Although the government has taken the necessary steps to promote the adoption of mobile technology in schools, more support and resources are still needed by the teachers in rural schools, especially for the great majority of disadvantaged families in the community. In the future, teacher development in integrating mobile teaching should cover ongoing experiences in the use of new devices so that teachers can be kept up to date with the ever-changing mobile teaching. Under the constraint of government budget, the integration of societal resources is also needed to support children's learning with new technology. Teachers in rural schools should also reach out for external funding and resources from other organizations and institutions. Adequate facilities and manpower to help children in remote areas is essential for bridging the divide in mobile learning opportunities. More involvement from the society to help teachers to cope with the tensions to integrating tablets in teaching and learning in remote areas is also suggested.

The research had the limitation that the research data were only gathered from volunteer teachers with mobile teaching experience. In the future, the scope of research should be extended to cover more teachers with different teaching domains and technology backgrounds to study tensions in technology integration from different perspectives.

\section{Acknowledgements}

This project was supported by the Ministry of Science and Technology under number MOST 102-2511-S-030001. The author would like to express her appreciation to MOST for the generous sponsorship.

\section{References}

Afshari, M., Bakar, K. A., Su Luan, W., Samah, B. A., \& Fooi, F. S. (2009). Factors Affecting Teachers' Use of Information and Communication Technology. International Journal of Instruction, 2, 77-104. http://eric.ed.gov/?id=ED524156

Al-Senaidi, S., Lin, L., \& Poirot, J. (2009). Barriers to Adopting Technology and Learning in Oman. Computer \& Education, 53, 575-590. http://dx.doi:10.1016/j.compedu.2009.03.015

Banister, S., \& Reinhart, R. V. (2011). TPCK for Impact: Classroom Teaching Practices that Promote Social Justice and Narrow the Digital Divide in an Urban Middle School. Computers in the Schools, 28, 5-26. http://eric.ed.gov/?id=EJ918076

Binsaleh, S., \& Binsaleh, M. (2013). Mobile Learning: What Guidelines Should We Produce in the Context of Mobile Learning Implementation in the Conflict Area of the Four Southernmost Provinces of Thailand. Asian Social Science, 9 , 270-281. http://dx.doi.org/10.5539/ass.v9n13p270

Blackwell, C. (2013). Teacher Practices with Mobile Technology Integrating Tablet Computers into the Early Childhood Classroom. Journal of Education Research, 7, 231-255. http://cmhd.northwestern.edu/wp-content/uploads/2014/07/Blackwell-JEDR-Final.pdf 
Butler, D. L., \& Sellbom, M. (2002). Barriers to Adopting Technology to Teaching and Learning. Educause Quarterly, 2, 22-28. http://cmapspublic3.ihmc.us/rid=1KC10V38V-C21PMV-GG/Barriers\%20To\%20Technology.pdf

Celano, D., \& Neuman, S. B. (2010). Roadblocks on the Information Highway. Educational Leadership, 68, 50-53.

Collier, D., Burkholder, K., \& Branum, T. (2013). Digital Learning: Meeting the Challenges and Embracing the Opportunities for Teachers. Committee for Economic Development (ERIC Reproduction Services: ED 544368).

https://www.ced.org/pdf/Digital_Learning_Issue_Brief_Final.pdf

ChanLin, L., Lin, H., \& Lu, T. (2015). College Students' Engagement in E-Tutoring Children in Remote Area. Innovations in Education and Teaching International. http://www.tandfonline.com/doi/abs/10.1080/14703297.2015.1015593?journalCode=riie20

Diaz, J. C. T., Moro, A. I., \& Carrión, P. V. T. (2015). Mobile Learning: Perspectives. Revista de Universidad y Sociedad del Conocimiento, 12, 38-49. http://link.springer.com/article/10.7238/rusc.v12i1.1944

DiVall, M. V., \& Zgarrick, D. P. (2014). Perceptions and Use of iPad Technology by Pharmacy Practice Faculty Members. American Journal of Pharmaceutical Education, 78, Article 52. http://www.ajpe.org/doi/full/10.5688/ajpe78352

Ducate, L., \& Lomicka, L. (2013). Going Mobile: Language Learning with an Ipod Touch in Intermediate French and German Classes. Foreign Language Annals, 46, 445-468. http://onlinelibrary.wiley.com/doi/10.1111/flan.12043/abstract

Engeström, Y. (1987). Learning by Expanding: An Activity Theoretical Approach to Developmental Research. Helsinki, Finland: Orienta-Konsultit. http://lchc.ucsd.edu/mca/Paper/Engestrom/Learning-by-Expanding.pdf

Fabian, K., \& MacLean, D. (2014). Keep Taking the Tablets? Assessing the Use of Tablet Devices in Learning and Teaching Activities in the Further Education Sector. Research in Learning Technology, 22, 1-14. http://dx.doi.org/10.3402/rlt.v22.22648

Fowler, R. H. (2012). Rural Characteristics and Values: A Primer for Rural Teachers from Non-Rural Backgrounds. National Teacher Education Journal, 5, 75-80.

http://eds.a.ebscohost.com/eds/pdfviewer/pdfviewer?vid=3\&sid=bfa0cfeb-8271-496f-90a 7-568623d61a1c\%40sessionmgr $\underline{4001 \& h i d=4103}$

Geist, E. (2014). Using Tablet Computers with Toddler and Young Preshcools. YC: Young Children, 69, 58-63. http://search.proquest.com/openview/66ba24507ade2b788e3f02f55136f4ff/1?pq-origsite=gscholar

Gerard, J. G., Knott, M. J., \& Lederman, R. E. (2012). Three Examples Using Tablet Technology in an Active Learning Classroom: Strategies for Active Learning Course Design Using Tablet Technology. Global Education Journal, 4, 91-114.

Henderson, R. (2011). Classroom Pedagogies, Digital Literacies and the Home-School Digital Divide. International Journal of Pedagogies \& Learning, 6, 152-161. http://www.tandfonline.com/doi/abs/10.5172/ijpl.2011.152

Hew, K. F., \& Brush, T. (2007). Integrating Technology into K-12 Teaching and Learning: Current Knowledge Gaps and Recommendations for Future Research. Education Technology Research and Development, 55, 223-252. http://dx.doi.org/10.1007/s11423-006-9022-5

Jaradat, S., Qablan, A., \& Barham, A. (2011). An Activity Theory Approach to Analyze Barriers to a Virtual Management Information Systems (MIS) Curriculum. Journal of Interactive Online Learning, 10, 15-35. http://www.ncolr.org/jiol

Jeng, Y. L., Wu, T. T., Huang, Y. M., Tan, Q., \& Yang, S. J. (2010). The Add-On Impact of Mobile Applications in Learning Strategies: A Review Study. Educational Technology \& Society, 13, 3-11. http://www.jstor.org/stable/jeductechsoci.13.3.3

Jill, B., \& Penny, D. (2010). Library Design, Learning Spaces and Academic Literacy. New Library World, 111, 480-492. http://www.emeraldinsight.com/doi/full/10.1108/03074801011094859 http://dx.doi.org/10.1108/03074801011094859

Kaiser, H. F. (1974). An Index of Factorial Simplicity. Psychometrika, 39, 31-36. http://dx.doi.org/10.1007/BF02291575 http://link.springer.com/article/10.1007\%2FBF02291575

Karlsudd, P. (2014). Tablets as Learning Support in Special Schools. Problems of Education in the 21st Century, 59, 49-58. http://www.scientiasocialis.lt/pec/?q=node/895

Kearney, M., Schuck, S., Burden, K., \& Aubusson, P. (2012). Viewing Mobile Learning from a Pedagogical Perspective. Research in Learning Technology, 20, 14406. http://dx.doi.org/10.3402/rlt.v20i0.14406

Khan, M. S. H., Hasan, M., \& Clement, C. K. (2012). Barriers to the Introduction of ICT into Education in Developing Countries: The Example of Bangladesh. International Journal of Instruction, 5, 61-80. http://www.e-iji.net/dosyalar/iji 2012 2 4.pdf

Kumbargoudar, P. (2013). Digital Divide in India: Problems and Prospects to Bridge the Divide. Golden Research Thoughts, 2, 1-9. http://connection.ebscohost.com/c/articles/91253272/digital-divide-india-problems-prospects-bridge-divide

Kuutti, K. (1995). Activity Theory as a Potential Framework for Human-Computer Interaction Research. In B. A. Nardi (Ed.), Context and Consciousness: Activity Theory and Human-Computer Interaction (pp. 17-44). Cambridge, MA: The MIT Press. https://www.ics.uci.edu/ corps/phaseii/nardi-ch2.pdf 
Laferrière, T., Hamel, C., \& Searson, M. (2013). Barriers to Successful Implementation of Technology Integration in Educational Settings: A Case Study. Journal of Computer Assisted Learning, 29, 463-473.

http://onlinelibrary.wiley.com/doi/10.1111/jcal.12034/abstract

http://dx.doi.org/10.1111/jcal.12034

Leont'ev, A. (1978). Activity, Consciousness, and Personality. Englewood Cliffs, NJ: Prentice-Hall.

https://www.marxists.org/archive/leontev/works/activity-consciousness.pdf

Liaw, S.-S., \& Huang, H.-M. (2014). Investigating Learner Attitudes toward E-Books as Learning Tools: Based on the Activity Theory Approach. Interactive Learning Environments, 24, 625-643.

http://www.tandfonline.com/doi/abs/10.1080/10494820.2014.915416\#preview

Martinez, M. E. (2010). Learning and Cognition: The Design of the Mind. London: Pearson College Division.

Middleton, M., Dupuis, J., \& Tang, J. (2013). Classrooms and Culture: The Role of Context in Shaping Motivation and Identity for Science Learning in Indigenous Adolescents. International Journal of Science \& Mathematics Education, 11, 111141. http://link.springer.com/article/10.1007\%2Fs10763-012-9385-5\#page-1

http://dx.doi.org/10.1007/s10763-012-9385-5

Ministry of Education in Taiwan (2014). Mobile Learning Project for Elementary and Secondary Schools. http://mlearning.ntue.edu.tw/

Mishra, P., \& Koehler, M. J. (2006). Technological Pedagogical Content Knowledge: A Framework for Teacher Knowledge. Teachers College Record, 108, 1017-1054. http://dx.doi.org/10.1111/j.1467-9620.2006.00684.x http://punya.educ.msu.edu/publications/journal articles/mishra-koehler-tcr2006.pdf

Nedungadi, P., \& Raman, R. (2012). A New Approach to Personalization: Integrating E-Learning and M-Learning. Educational Technology Research \& Development, 60, 659-678. http://dx.doi.org/10.1007/s11423-012-9250-9

http://link.springer.com/article/10.1007/s11423-012-9250-9?no-access=true

Neumann, M., \& Neumann, D. (2014). Touch Screen Tablets and Emergent Literacy. Early Childhood Education Journal, 42, 231-239. http://dx.doi.org/10.1007/s10643-013-0608-3

http://resourcebinderecse.weebly.com/uploads/2/0/1/3/20133951/neuman_touch_screen_tablets_and_emerg_lit.pdf

Oyserman, D. (2013). Not Just Any Path: Implications of Identity-Based Motivation for Disparities in School Outcomes. Economics of Education Review, 33, 179-190. http://www.sciencedirect.com/science/article/pii/S0272775712001148

Ozan, O. (2013). Scaffolding in Connectivist Mobile Learning Environment. Turkish Online Journal of Distance Education (TOJDE), 14, 44-54.

Park, Y. (2011). A Pedagogical Framework for Mobile Learning: Categorizing Educational Applications of Mobile Technologies into Four Types. The International Review of Research in Open and Distance Learning, 12, 78-102. http://www.irrodl.org/index.php/irrodl/article/view/791/1699

Peterson, P. (2011). Saving Schools: From Horace Mann to Virtual Learning. Cambridge, MA: Harvard University Press.

Phiri, A. C., Foko, T., \& Mahwai, N. (2014). Evaluation of a Pilot Project on Information and Communication Technology for Rural Education Development: A Cofimvaba Case Study on the Educational Use of Tablets. International Journal of Education \& Development Using Information \& Communication Technology, 10, 60-79.

http://ijedict.dec.uwi.edu/viewarticle.php?id=1866

Riley, P. (2013). Teaching, Learning, and Living with iPads. Music Educators Journal, 100, 81-86.

http://mej.sagepub.com/content/100/1/81.abstract http://dx.doi.org/10.1177/0027432113489152

Scott, P. G. (2014). Flipping the Flip. Educational Leadership, 71, 73-75. http://eric.ed.gov/?id=EJ1043766

Schmidt, D. A., Baran, E., Thompson, A. D., Koehler, M., Mishra, P., \& Shin, T. (2009). Technological Pedagogical Content Knowledge (TPACK): The Development and Validation of an Assessment Instrument for Preservice Teachers. Journal of Research and Technology in Education, 42, 123-149. http://punya.educ.msu.edu/publications/schmidt-et.al.2010.pdf http://dx.doi.org/10.1080/15391523.2009.10782544

Sharples, M., Taylor, J., \& Vavoula, G. (2005). Toward a Theory of Mobile Learning. In: 4th Conference on mLearning. http://www.mlearn.org.za/CD/papers/Sharples.pdf

Schlicht, P. (2013). Turning the Digital Divide into Digital Dividends through Free Content and Open Networks: WikiEducator Learning4Content (L4C) Initiative. Journal of Asynchronous Learning Networks, 17, 87-100. http://eric.ed.gov/?id=EJ1018280

Shulman, L. S. (1986). Those Who Understand: Knowledge Growth in Teaching. Educational Researcher, 15, 4-14. http://www.jstor.org/stable/1175860?seq=1\#page scan tab contents http://dx.doi.org/10.3102/0013189X015002004 
Tondeur, J., Keer, H. V., Braak, J. V., \& Valcke, M. (2008). ICT Integration in the Classroom: Challenging the Potential of a School Policy. Computers \& Education, 51, 212-223. http://dx.doi.org/10.1016/j.compedu.2007.05.003 http://www.sciencedirect.com/science/article/pii/S0360131507000498

Watson, S. L., \& Watson, W. R. (2011). The Role of Technology and Computer-Based Instruction in a Disadvantaged Alternative School's Culture of Learning. Computers in the Schools, 28, 39-55. http://www.tandfonline.com/doi/abs/10.1080/07380569.2011.552042

\section{Submit or recommend next manuscript to SCIRP and we will provide best service for you:}

Accepting pre-submission inquiries through Email, Facebook, Linkedin, Twitter, etc A wide selection of journals (inclusive of 9 subjects, more than 200 journals)

Providing a 24-hour high-quality service

User-friendly online submission system

Fair and swift peer-review system

Efficient typesetting and proofreading procedure

Display of the result of downloads and visits, as well as the number of cited articles

Maximum dissemination of your research work

Submit your manuscript at: http://papersubmission.scirp.org/ 